\title{
POSITIONAL ACCURACY OF AEROPHOTOGRAMMETRIC SURVEY IN THE PANTANAL DERIVED FROM UAV
}

\author{
PRECISÃO POSICIONAL DE LEVANTAMENTO AEROFOTOGRAMÉTRICO NO PANTANAL \\ REALIZADO COM VANT
}

\section{Anny Keli Aparecida Alves CÂNDIDO ${ }^{1}$, Antonio Conceição PARANHOS FILHO ${ }^{2}$, José MARCATO JÚNIOR ${ }^{2}$, Normandes Matos da SILVA ${ }^{1}$, Marcelo Ricardo HAUPENTHAL ${ }^{2}$, José Renato Silva de OLIVEIRA ${ }^{2}$, Leandro Bonfietti MARINI², André Marcondes Andrade TOLEDO ${ }^{3}$

\author{
${ }^{1}$ Universidade Federal de Mato Grosso. Emails: anny.keli@hotmail.com; normandes@ufmt.br \\ 2Universidade Federal de Mato Grosso do Sul. Emails: antonio.paranhos@pq.cnpq.br; jrmarcato@gmail.com; haupen@gmail.com; \\ j.reenatoo@gmail.com; leandrobonfietti@gmail.com \\ ${ }^{3}$ Universidade Federal de São Carlos. Email: amatoledo@gmail.com
}

\author{
Introduction \\ Materials and Methods \\ Results and Discussion \\ Conclusion \\ Thanks \\ References
}

\begin{abstract}
RESUMO - O objetivo deste trabalho foi analisar as distorções geométricas de um mosaico de fotografias aéreas realizado por veículo aéreo não tripulado (VANT), gerado com dados de uma navegação GPS de aeronaves controladas remotamente, em relação aos pontos de controle coletados no campo com um RTK. A imagem foi realizada em 9 de agosto de 2014, na base de pesquisa UFMS no Pantanal de Mato Grosso do Sul, com um motor de propulsão elétrica e aeronave de asa fixa. O voo foi conduzido a uma altitude de $150 \mathrm{~m}$, planejado de forma a obter pixels com resolução espacial de aproximadamente $4 \mathrm{~cm}$. Para verificar a precisão do mosaico foram coletados pontos de controle de um receptor GNSS HIPER. Para facilitar a localização dos pontos em fotografias aéreas foram feitas marcas no chão. O mosaico sem ponto de controle apresentou deslocamento variando de 6,30 m a 8,83 m. Anteriormente, os alvos com 1 , 2 e 3 pontos de controle apresentaram pequenos erros considerando a legislação para georreferenciamento de propriedades rurais. Os produtos gerados a partir de pontos de controle têm alta precisão planialtimétrica e são susceptíveis de serem utilizados em trabalhos que exigem precisão de posicionamento, tais como serviços especializados de registro e georreferenciamento de propriedades rurais, análise de culturas e quantificação de flora e fauna.
\end{abstract}

Palavras-chave: Drone; UAV; fotogrametria; gestão ambiental; geotecnologia.

\begin{abstract}
The objective of this work was to analyze the geometric distortions of aerial photographs mosaic derived from unmanned aerial vehicle (UAV) generated with data from a GPS navigation engaged in remotely piloted aircraft in relation to the field collected control points with an RTK. The imaging was performed on August 9, 2014, at UFMS research base in the Pantanal of Mato Grosso do Sul, with a fixed-wing aircraft and electric propulsion motor. The flight was conducted at an altitude of $150 \mathrm{~m}$, planned in such a way to obtain pixels with about $4 \mathrm{~cm}$ spatial resolution. To check the accuracy of the mosaic were collected control points from a GNSS HIPER receiver. To ease the location of points on aerial photographs were made markings on the ground. Mosaic without control point presented displacement ranging from $6.30 \mathrm{~m}$ to $8.83 \mathrm{~m}$. Previously the tiles with 1,2 and 3 control points had low errors, given the legislation for the georeferencing of rural properties. Products generated from controls points have high planialtimetric accuracy and are likely to use in jobs that require high positional accuracy, such as expertise services, registration and georeferencing of rural properties, crops analysis and flora and fauna quantification.

Keywords: Drone; UAV; photogrammetry; environmental management; geotechnology.
\end{abstract}

\section{INTRODUCTION}

Obtaining images by Unmanned Aerial Vehicle (UAV) is a promising new technology and is becoming more popular among the geotecnologies due to technical and economic advantages. The regulations that are about to inure in Brazil is another factor which confirms this growth, as it will guide the marketing and use of these in the country.

Many companies are developing compact aircraft with lighter and stronger materials, equipped with high technology and small size sensors. Everaerts (2008) reports that UAVs are increasingly autonomous and modern, with a range of sensors facing the most diverse applications, making it an advantage to monitoring, therefore, allow the sensors to be selected and configured according to the every job goal.

Alves Junior et al. (2014) report that although many of the UAV are equipped with GNSS receivers (Global Navigation Satellite Systems), they are not able to perform a rectilinear trajectory or even maintain flight altitude, resulting in problems with scale and the lateral and longitudinal photograph overlaps. The lack or reduction of overlaps may result in areas without photographic coverage or inadequate coverage.

The difference in scale of an orbital or 
suborbital image are caused at the time that the sensor captures the spectral response of morphologically distinct objects and elevations above or below the average terrain, what generates images at different scales and with some distortions, making necessary to make corrections (Jensen, 2009).

Due to the high spatial resolution rate of the UAV images, there is the possibility of obtaining high accuracy positional. Knowing that the error of the geometric correction may be less of a pixel and the pixel size in this type of aerial photography is in a centimetric scale, the use of DGPS for positional correction of these images turns essential.

Alves Junior et al. (2015) who worked with validation orthomosaics and digital UAV surface models concluded that there is need for support points for the generation of cartographic products from aerial photographs of UAVs.

Thus, the aim of this study was to evaluate the positional accuracy of planialtimetric photo mosaics generated without control points and DGPS points obtained in the field.

The products generated are pliable to use in geo-referencing of rural properties, since INCRA technical positioning manual provides that obtaining geometric information for Remote Sensing of physical elements, indirectly, accurately and appropriately assessed reliability (Brazil, 2013b).

And the use of orthorectified images obtained by UAV can be of great rating for the determination of natural boundaries coordinates and inaccessible places, as the Law 10,267 / 01 (Brazil, 2001) updated in 2013 (Brazil, 2013a) sets the error up between 3.00 meters and 7.5 meters respectively.

\section{MATERIALS AND METHODS}

The Pantanal is a major surface accumulation plan with altitude ranging between 80 and 150m (Adámoli, 1986), which can be subdivided into 18 regions (Figure 1A) and has an area of 140,640 $\mathrm{km}^{2}$ (Mioto et al. 2012).
The same authors report that most of the Pantanal territory lays within Brazil's political boundary, and the region of Nabileque / Chaco occupies part of the territory of Bolivia and Paraguay.
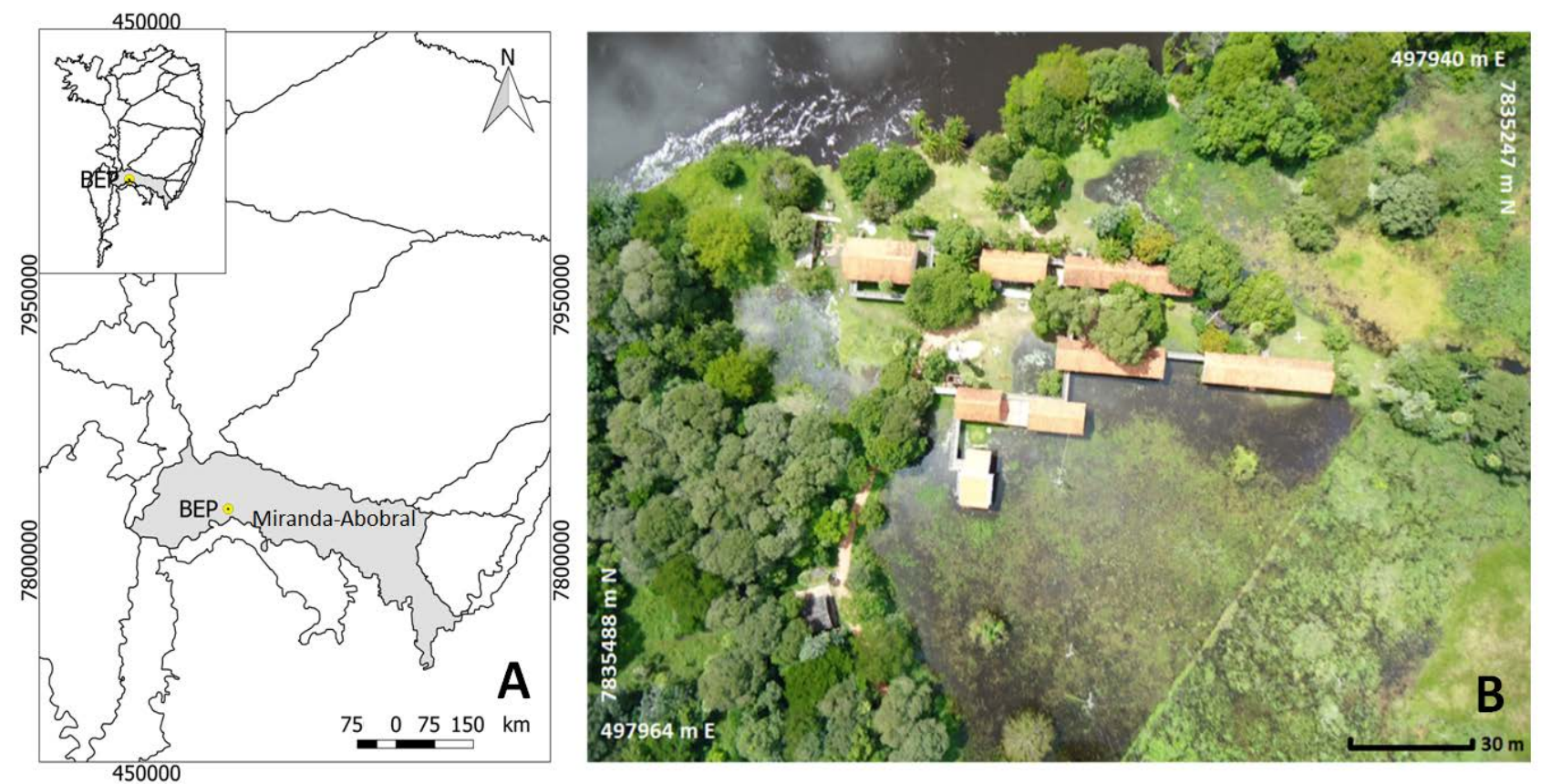

Figure 1 - Divisions of the Pantanal accordingly to Mioto et al. (2012), highlighting the Miranda-Abobral region where is located the BEP - Research Base in Pantanal UFMS. On the right side an aerial photograph of the UAV BEP with a spatial resolution of approximately $4 \mathrm{~cm}$.

The UAV mission occurred in the Pantanal Research Base (BEP) UFMS located at latitude 19³4'37,91 "S and longitude 5701'06.37" $\mathrm{O}$, in the Corumbá city, Mato Grosso do Sul, in place called Passo do Lontra, Pantanal Miranda-Abobral (Figura 1B).

BEP has 21.5 ha with built area of $1,208 \mathrm{~m}^{2}$ on the river Miranda and offers accommodation for 
up to 33 people, dining room, pantry, laundry room, machine room with generator, rural electricity, laboratories, rooms class, room for library and clinic to perform medical and dental care and clinical analysis for the local population (Propp, 2014). BEP is of top importance for the development of research in this biome, since it presents a different dynamic and is underexplored; it needs to be better scientifically understood. Featuring a wealth of fauna and flora it becomes necessary to know it better in order to create guidelines for its preservation.

The planning area to be imaged was held on the Free Software Mission Planner (Oborne, 2014), in which parameters are defined as flight time and the route of the mission.

This step is made in accordance with the purpose of the work, since the higher UAV flying height, greater will be imaged area and lower spatial resolution there will be.

Another factor that should be taken into consideration is flight autonomy of each aircraft, since there is great variation in flight time according to each aircraft.

The flight range may vary according to the payload carried on by the UAV, model and size of the UAV, as well as the power and the type of battery used in each aircraft.

Other factors considered were the weather conditions of the region on the imaging, the speed and wind direction as strong winds hamper the mission, as well as a suitable place for aircraft landing and takeoff and the performed mission weather, because the picture quality is directly weather light dependent (around noon) and can reduce shadows on the images.

The imaging was carried out on 9 August 2014, with a fixed wing aircraft and electric propulsion motor (Figure 2).

The flight was conducted at an altitude $150 \mathrm{~m}$, planned in such a way to obtain pixels with about $4 \mathrm{~cm}$ spatial resolution. W320 14 Megapixels - a Sony DSC was used.

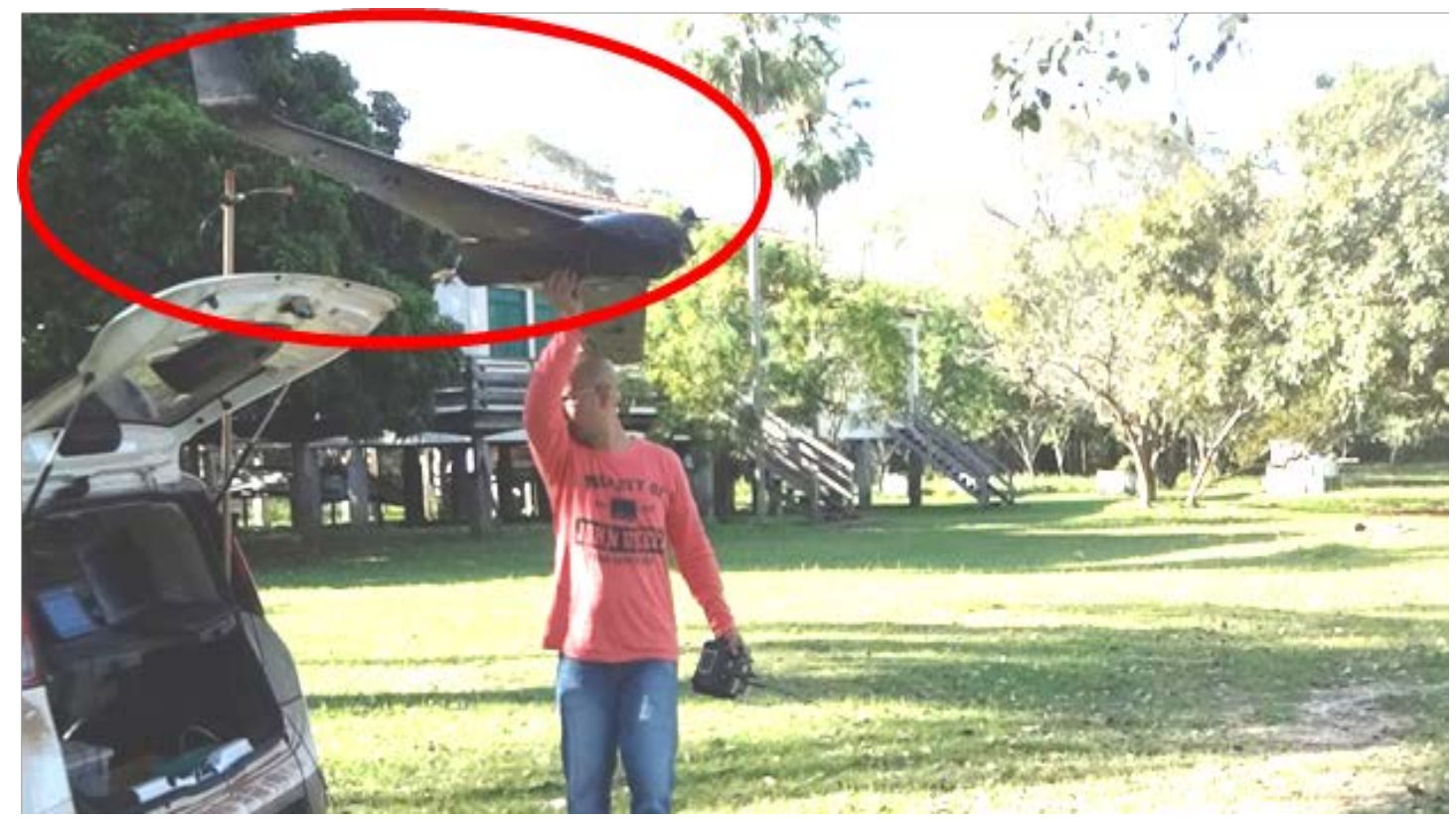

Figure 2 - Highlights the remotely piloted aircraft electric propulsion used in the research.

After the flight mission the data was analyzed in the Mission Planner (Oborne, 2014), it was later also made the photos matching with the flight log (Geotag), in this stage each photo received location and altimetry information based on data from UAV GPS.

Throughout the mission were collected points location from a GNSS receiver HYPER SR with positioning accuracy in static mode (L1 / L2) of 3 $\mathrm{mm}+0.5$ ppm horizontally and $5 \mathrm{~mm}+0.5 \mathrm{ppm}$ vertically.
The projection system adopted in the study was the UTM zone 21S with WGS 84. The survey of control points was carried out with dual frequency GNSS receivers, applying the RTK positioning technique (Real Time Kinematic).

To facilitate the points location of the aerial photographs were made markings on the ground (Figure 3) with light and darkness powder (white grout and graphite). Depending on the soil cover was chosen grout color to give greater contrast with the substrate. 


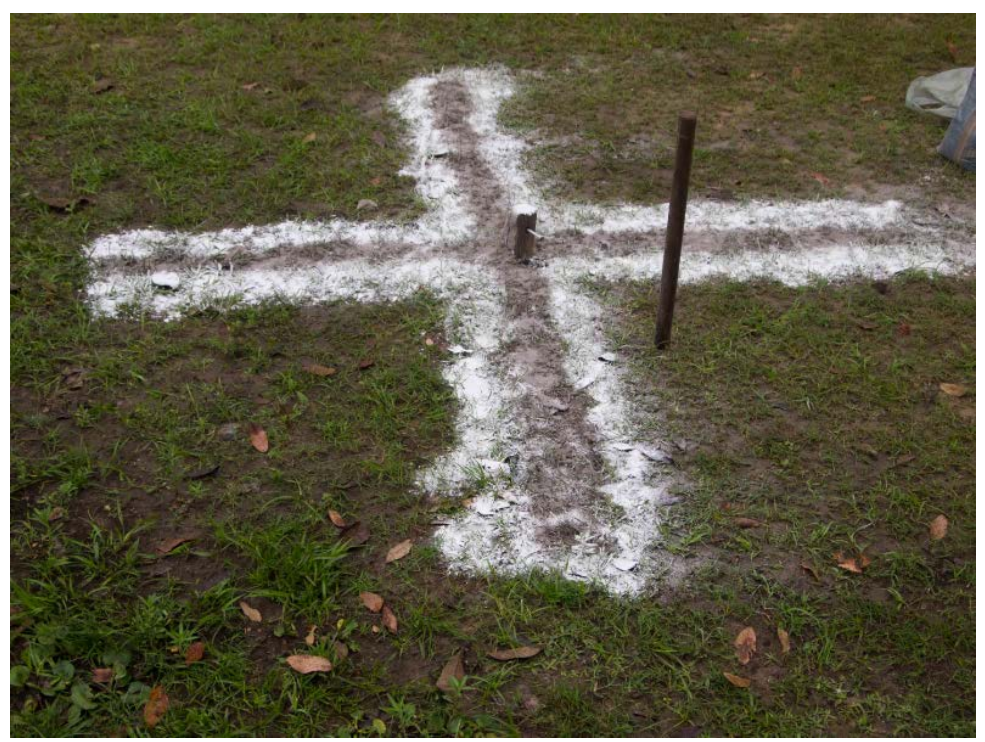

Figure 3 - Ground marking to collect the planialtimetric control point adopted in the validation and correction of UAV aerial photographs mosaic.

The UAV photographs mosaic was generated in Agisoft Photoscan software (Agisoft, 2014) by importing the image file and text file with flight data related to positioning at the time of obtaining the images. The center coordinates of each photograph were identified and used by software to make the mosaic.

The displacement of the mosaic generated from the UAV photos were evaluated by plotting the control points on it and then measuring the distance between the inserted point and field marking that is in the mosaic (marking $\mathrm{X}$ with white powder) where these points (RTKs) have been properly measured.

For the orthorectification of the photo mosaic was generated a digital surface model (DSM). And for viewing the MDS in 3D mode was used Global Mapper 13.2 (Blue Marble GeoGraphics, 2012).

The analysis of the displacement direction between the mosaic for the points control was performed through the azimuth and heading calculated for each control point. The same was generated from CadTools QGIS plug (Ziegler, 2014) using two points, differential global positioning system (DGPS) and mosaic.

To calculate the root mean square error (RMSE), mosaics were made with 1 point, 2 points and 3 points of control, with all possible combinations of 5 points.

The points that were not used in the mosaic correction were used in a second stage as a control to measure the displacement of the tile and to obtain the RMSE. The RMSE was obtained by the formula below (Eq. 1).

$$
\begin{aligned}
& R E Q M=\sqrt{\frac{\sum_{i=1}^{n}\left(X_{m-} X_{G}\right)^{2}}{n}} \quad \text { Eq. } 1 \\
& \mathrm{n}=\text { number of coordinates used to control; } \\
& \mathrm{X}_{\mathrm{M}}=\text { coordinated mosaic; } \\
& \mathrm{X}_{\mathrm{G}}=\text { coordinated estimated by RTK. }
\end{aligned}
$$

\section{RESULTS AND DISCUSSION}

Through the photographic record of the region it was possible to generate products such as Digital Surface Model (DSM) and orthorectified mosaics.The DSM generated shows that the lower region, flooded, has a height of $67 \mathrm{~m}$, in not flooded areas the found altitude was approximately $88 \mathrm{~m}$ and maximum altitude is $113 \mathrm{~m}$ at the trees (Figure 4).

According Maune (2011) MDS are relevant to telecommunications management, air safety, forest management, 3D modeling and artifacts simulations on the ground.
The obtained MDS from UAV photographs is an important tool for orthorectification of images to show small variations in the height of objects present on the surface, it captures small altitude field variations due to its high spatial resolution.

In figure 4 you can see masonry buildings in the center with rectangular shape (seta1), a fence located vertically on the left side (arrow 2), small ripples after around the left side due to grasses (arrow 3), vegetation canopies arboreal (arrow 4), among other features present there. 


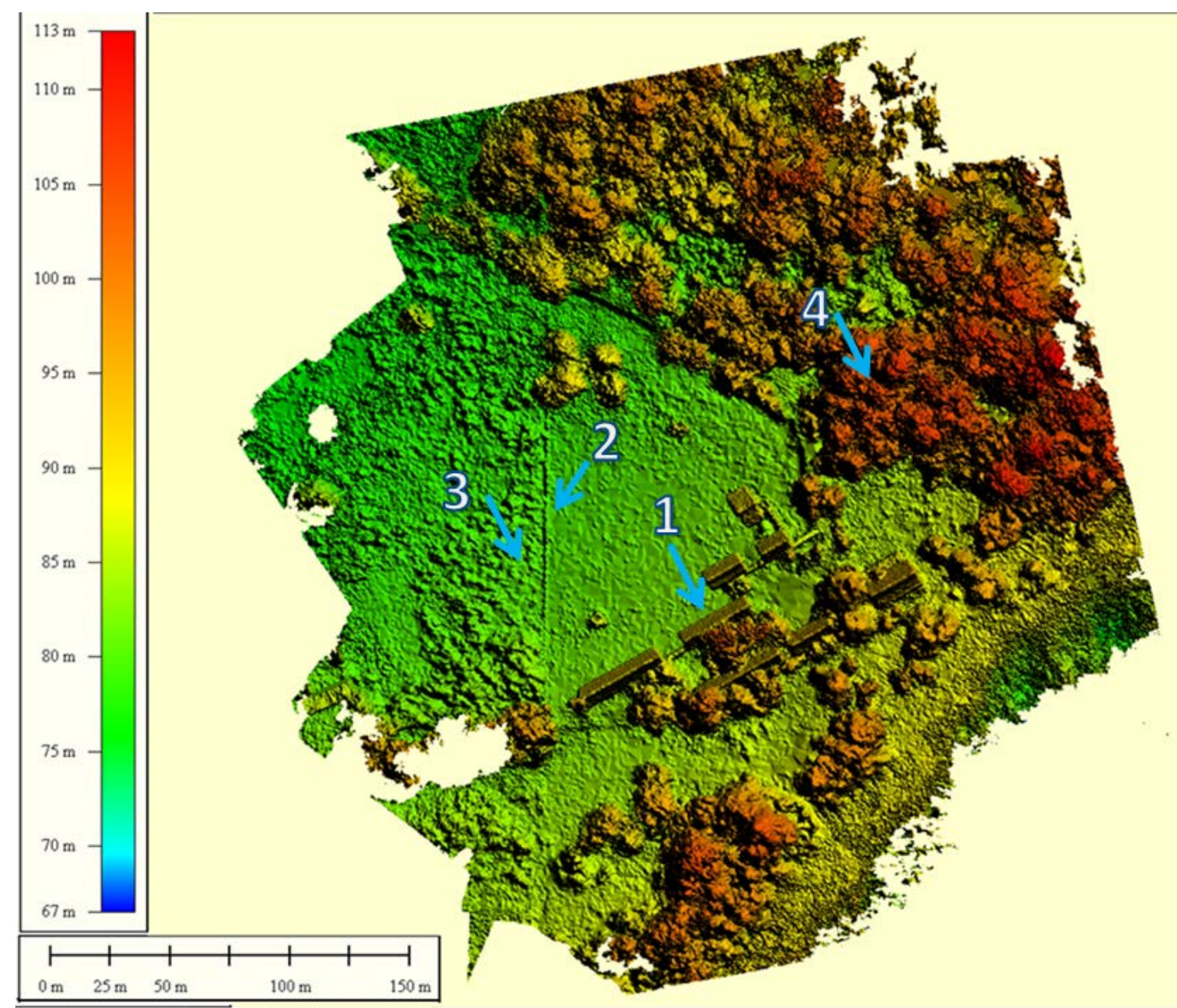

Figure 4 - Digital model preview surface - MDS obtained through aerial photography, 3D visualization with shading in Global Mapper version 13.2 software (Blue Marble GeoGraphics, 2012).

These different features that make up the picture become even more evident when visualized in 3D MDS with the overlap of aerial photographs mosaic (Figure 5). In this case the color, texture, shadows help us identify different features of the study area.

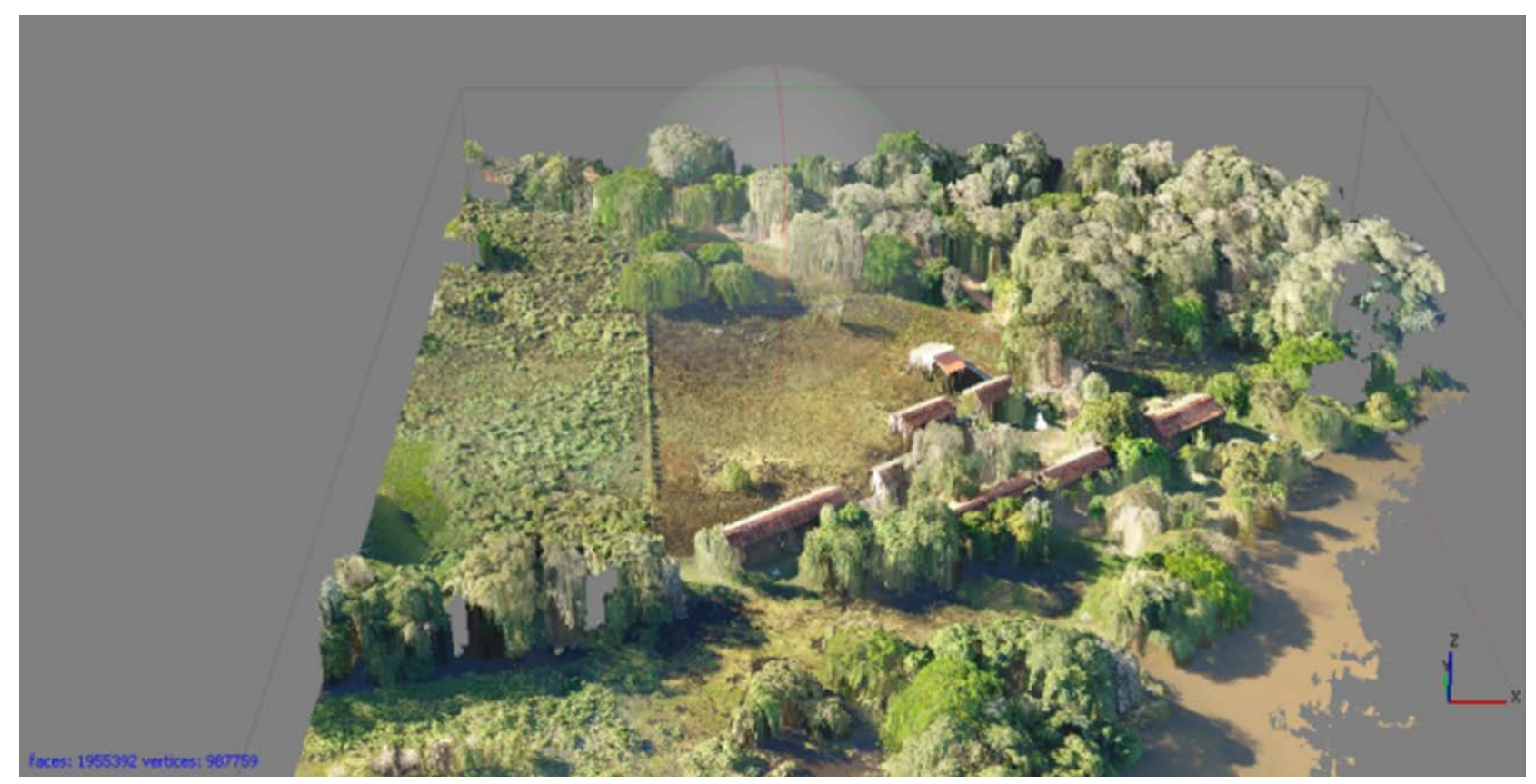

Figure 5 - MDS 3D 5 visualization of overlapped with the mosaic of aerial photographs. 
The spatial resolution mosaic generated is approximately $4 \mathrm{~cm}$, which allows identification of electric wires in the red rectangle in the upper left corner near the fence, as well as electricity pylon, the markings which have been made to put the GPS tripods, different plant species, such as Carandá a typical palm region (red circles varius) and the car on which was based the UAV control (red arrow) (Figure 6).

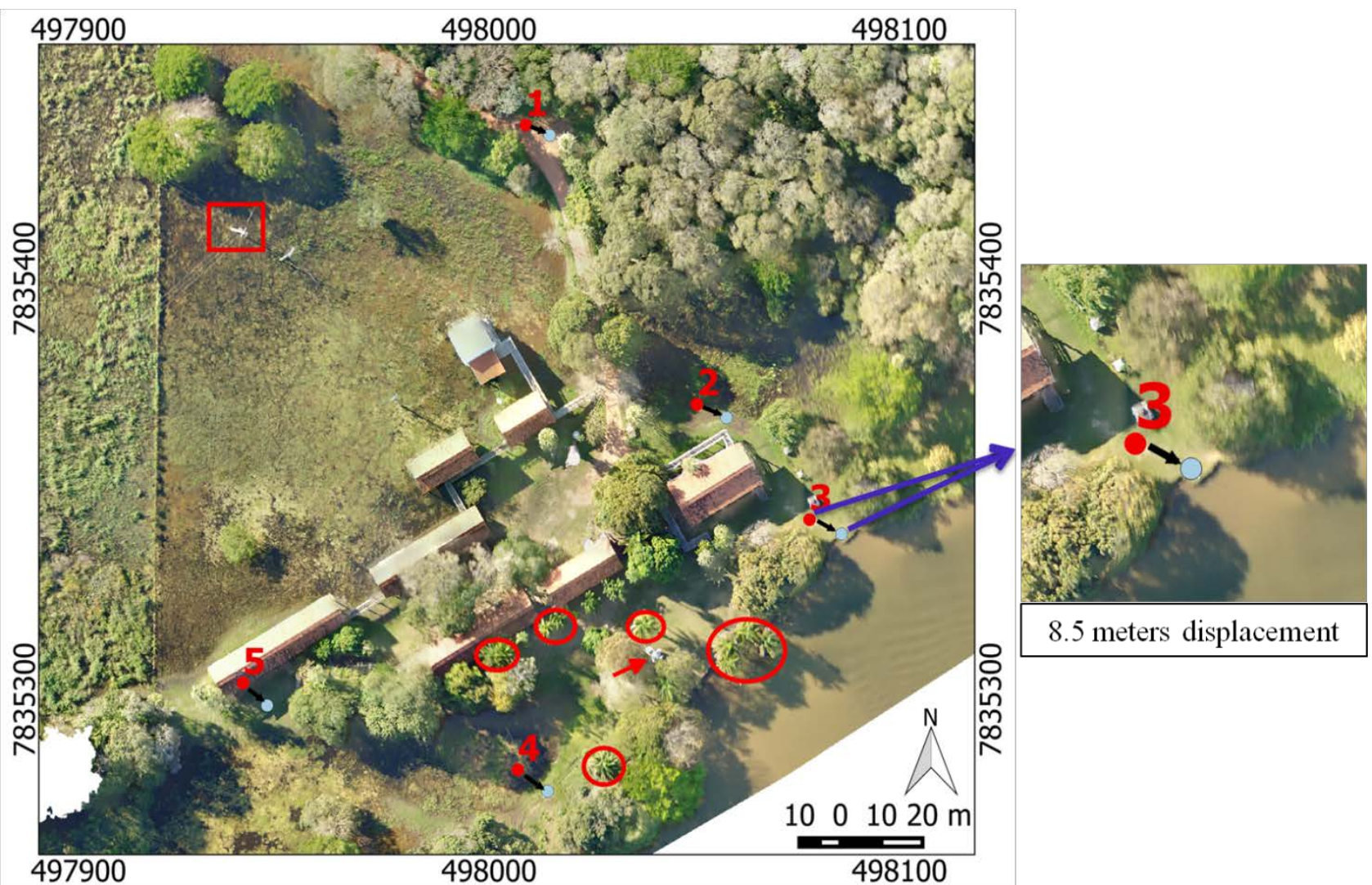

Figure 6 - Generated mosaic from the central coordinates of each photo, and highlighted the Carandá, a typical palm of the area (red circles), the UAV car base control (red arrow), a stake (rectangle in the upper figure) and the displacements of the control points, the example, 16 highlight point on the right side of the figure.

Comparing mosaic offset in relation to the control point there is an offset of $6.30 \mathrm{~m}$ in point 1 to $8.83 \mathrm{~m}$ in point 4 . It is observed that the largest shift in East are compared to North (Table 1).

Table 1 - Comparison of the coordinates of the control points obtained in the field (RTK) with the respective generated points collected in the mosaic only with the central coordinate of each photograph obtained through a GPS navigation, showing the shift in E, the distance $\mathrm{N}$ between the two points (RTK and Mosaic).

\begin{tabular}{c|c|c|c}
\hline Pontos & $\mathbf{E}$ & $\mathbf{N}$ & Deslocamento \\
\hline Points & East & North & Displacement \\
\hline $\mathbf{1}$ & $5.825 \mathrm{~m}$ & $2.416 \mathrm{~m}$ & $6.309 \mathrm{~m}$ \\
\hline $\mathbf{2}$ & $7.216 \mathrm{~m}$ & $3.072 \mathrm{~m}$ & $7.942 \mathrm{~m}$ \\
\hline $\mathbf{3}$ & $7.836 \mathrm{~m}$ & $3.308 \mathrm{~m}$ & $8.557 \mathrm{~m}$ \\
\hline $\mathbf{4}$ & $7.226 \mathrm{~m}$ & $5.053 \mathrm{~m}$ & $8.831 \mathrm{~m}$ \\
\hline $\mathbf{5}$ & $5.897 \mathrm{~m}$ & $5.329 \mathrm{~m}$ & $7.959 \mathrm{~m}$ \\
\hline
\end{tabular}

When evaluating the shift of the points obtained by the mosaic to the points of RTKs, there is a tendency for the points to always move in the same direction.

To make sense of displacement was calculated azimuth, or angle between the north and alignment, this angle ranges from $0^{\circ}$ to $360^{\circ}$ and is clockwise counted. It is observed little variation in azimuth, since they are within the second quadrant $\left(90^{\circ}\right.$ to $180^{\circ}$ ). The obtained angles range from $112.504^{\circ}$ to $132.313^{\circ}$, showing systematic and not random trend. This systematic trend is even more evident in figure 7 , where the red arrows indicate the direction of travel of the control points.

Alves Junior et al. (2015) also found that systematic trend mosaic without control points, though the authors showed a planimetric discrepancy in the general direction of $45^{\circ}$ and NE direction in most vectors, although, in this work directions have SE direction and range from $47.687^{\circ}$ in point 5 to $67.496^{\circ}$ in 1 . 

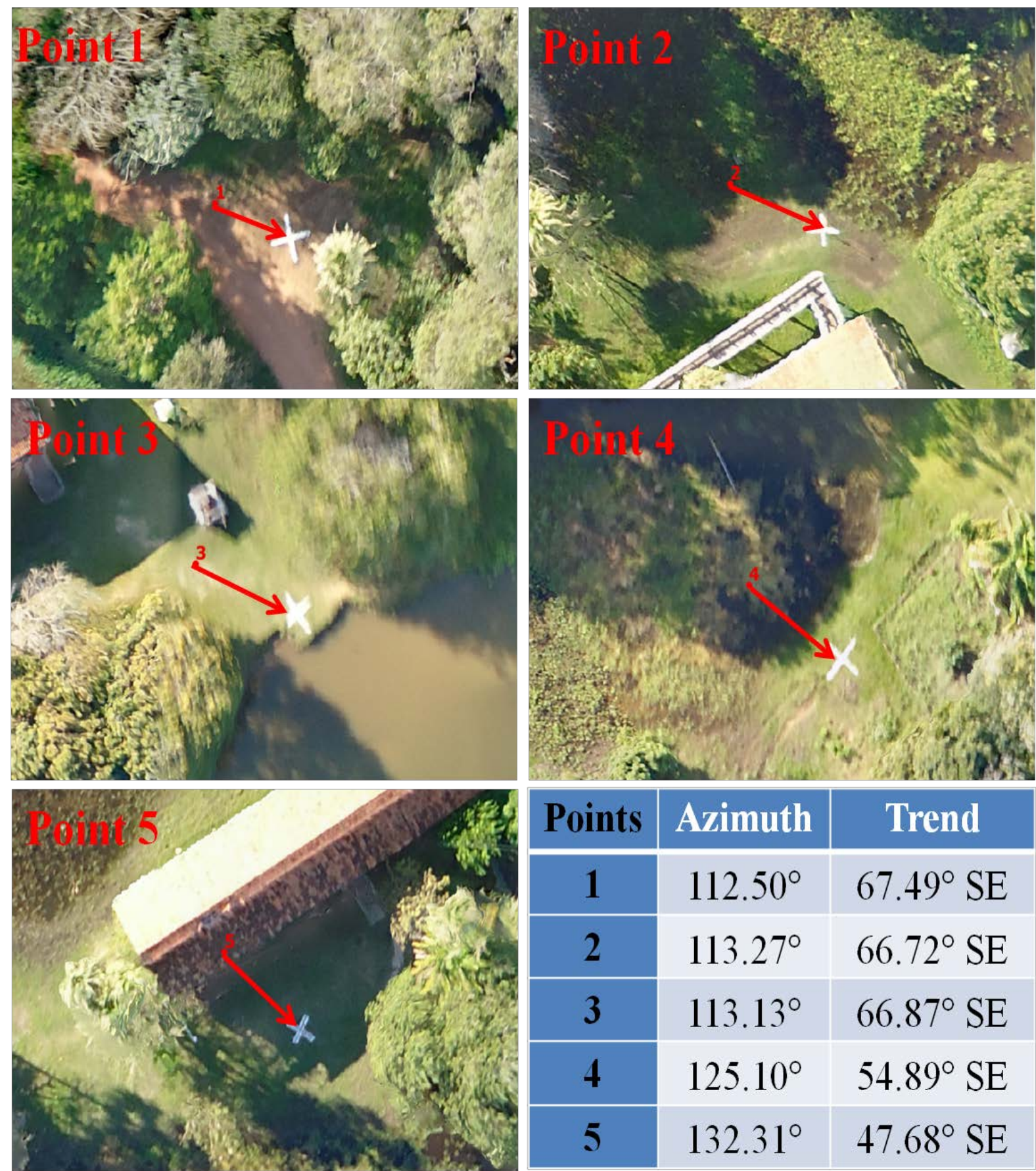

\begin{tabular}{|c|c|c|}
\hline Points & Avimuth & Trend \\
\hline $\mathbf{1}$ & $112.50^{\circ}$ & $67.49^{\circ} \mathrm{SE}$ \\
\hline $\mathbf{2}$ & $113.27^{\circ}$ & $66.72^{\circ} \mathrm{SE}$ \\
\hline $\mathbf{3}$ & $113.13^{\circ}$ & $66.87^{\circ} \mathrm{SE}$ \\
\hline $\mathbf{4}$ & $125.10^{\circ}$ & $54.89^{\circ} \mathrm{SE}$ \\
\hline $\mathbf{5}$ & $132.31^{\circ}$ & $47.68^{\circ} \mathrm{SE}$ \\
\hline
\end{tabular}

Figure 7 - Mosaic displacement direction measured by the azimuth and trend.

Much of this displacement can be reduced by inserting a few control points obtained from a GNSS receiver.

Tests carried out have shown that the insertion of the first control point mean square error obtained from the square root (RMSE) ranged from $0.53 \mathrm{~m}$ (1 point) to $1.59 \mathrm{~m}$ (2) in East direction and to North varied from 0.24 (point 1) to 1.02 (points 2 and 3) (Table 2). The RMSE is an effective mean of measuring accuracy, it is used by various authors as Lee Liew et al. (2012), Marcato Junior \& Tommaselli (2013) and Azmi et al. (2014).
When considered two control points for geometric correction errors it tends to reduce considerably, the biggest mistake found in East was $0.19 \mathrm{~m}$ at points 3 and 4 and $0.13 \mathrm{~m}$ in North considering points 2 and 3 .

The inclusion of 3 observed control points there was a greater reduction in RMSE, especially where the points were more scattered, but in places where the three-point inserted control were close, there was a $0,11 \mathrm{~m}$ error (points 1, 2, 3 and 2, 3, 4) and to $\mathrm{E}$ and $\mathrm{N}$ the biggest mistake found was $7 \mathrm{~mm}$ (points $1,4,5$ ) (Table 2). 
Table 2 - Mean Squared Error root (RMSE) generated from the comparison among the RTK points and the corresponding points on the tiles with geometric correction using 1, 2 and 3 control points.

\begin{tabular}{|c|c|c|c|}
\hline $\begin{array}{l}\text { Control } \\
\text { Points }\end{array}$ & $\begin{array}{c}\text { Checking } \\
\text { Points }\end{array}$ & $\begin{array}{c}\text { REQM E in } \\
\text { meters }\end{array}$ & $\begin{array}{c}\text { REQM N in } \\
\text { meters }\end{array}$ \\
\hline \multicolumn{4}{|c|}{1 point } \\
\hline 1 & $2,3,4,5$ & 0.531 & 0.240 \\
\hline 2 & $1,3,4,5$ & 1.597 & 1.022 \\
\hline 3 & $1,2,4,5$ & 1.134 & 1.020 \\
\hline 4 & $1,2,3,5$ & 0.922 & 0.513 \\
\hline 5 & $1,2,3,4$ & 1.284 & 0.545 \\
\hline \multicolumn{4}{|c|}{2 points } \\
\hline 1 e 2 & $3,4,5$ & 0.091 & 0.034 \\
\hline 1 e 3 & $2,4,5$ & 0.095 & 0.054 \\
\hline 1 e 4 & $2,3,5$ & 0.023 & 0.042 \\
\hline 1 e 5 & $2,3,4$ & 0.043 & 0.057 \\
\hline 2 e 3 & $1,4,5$ & 0.110 & 0.138 \\
\hline 2 e 4 & $1,3,5$ & 0.077 & 0.042 \\
\hline 2 e 5 & $1,3,4$ & 0.068 & 0.033 \\
\hline 3 e 4 & $1,2,5$ & 0.197 & 0.107 \\
\hline 3 e 5 & $1,2,4$ & 0.131 & 0.024 \\
\hline 4 e 5 & $1,2,3$ & 0.059 & 0.041 \\
\hline \multicolumn{4}{|c|}{3 points } \\
\hline 1,2 e 3 & 4,5 & 0.110 & 0.065 \\
\hline 1,2 e 4 & 3,5 & 0.025 & 0.030 \\
\hline 1,2 e 5 & 3,4 & 0.006 & 0.017 \\
\hline 1,3 e 4 & 2,5 & 0.031 & 0.060 \\
\hline 1,3 e 5 & 2,4 & 0.039 & 0.025 \\
\hline 1,4 e 5 & 2,3 & 0.043 & 0.075 \\
\hline 2,3 e 4 & 1,5 & 0.118 & 0.069 \\
\hline 2,3 e 5 & 1,4 & 0.102 & 0.003 \\
\hline 2,4 e 5 & 1,3 & 0.050 & 0.016 \\
\hline 3,4 e 5 & 1,2 & 0.071 & 0.016 \\
\hline
\end{tabular}

Eltohamy \& Hamza (2009) reported that for higher geometric accuracy correction of satellite images the location and distribution of the control points must be taken into consideration.

The results obtained with the inclusion of only one point perfectly met the rules for rural properties georeferencing, because INCRA positioning technical manual (Brazil, 2013b) mentions the use of remote sensing for geometric information and the current legislation (Brazil, 2013a) provides an error ranging from 3.00 to $7.5 \mathrm{~m}$ for natural limits and inaccessible places respectively, and the biggest mistake found in this work with the insertion of 1 point was $1.59 \mathrm{~m}$ to $1.02 \mathrm{~m}$ East and North.

Now with the addition of two points or more the RMSE would meet the legislation for the most demanding requirements which are the artificial boundaries in which the error cannot exceed $50 \mathrm{~cm}$. However, the INCRA positioning technical manual (Brazil, 2013b) determines to not use of remote sensing to determine the type "M" vertices, which are about fence vertices and related confrontation changes.

Regarding the altitude, the error is low and is in the order of centimeters, ranging from $3.7 \mathrm{~cm}$ in point 5 to $37.9 \mathrm{~cm}$ in point 4 . The altitudes of control points along with their errors can be checked in table 3.The images with high spatial resolution can be used for analysis of small areas, as done by Cândido et al. (2015a), as in the spring recovering area of São Lourenço River, MT. It can also be used for delimitation of small features through automatic classification of photographs from UAV (Cândido et al., 2015b).

Products generated with control points obtained from a dual-frequency receiver (RTK) with high positional quality can form the basis for a work development as the Environmental Impact Study / Environmental Impact Report (EIA / RIMA) and can be applied to all technical activities present in 
this study as required by Article 6 of Resolution CONAMA No. 001/86. It can also be used in the Rural Environmental Registration (CAR) due to the very same requirements and knowing that the new forest code adopts APP maintenance criteria and legal reserve in according to the set limits in the CAR, as well as support for rural properties georeferencing.

Table 3 - Comparison among the control points altitudes with MDS altitudes relating to those markings.

\begin{tabular}{c|c|c|c|c|c}
\hline Points & $\begin{array}{c}\text { Geometric } \\
\text { altitude (m) }\end{array}$ & $\begin{array}{c}\text { Geoidal } \\
\text { ondulation (m) }\end{array}$ & $\begin{array}{c}\text { Ortometric } \\
\text { altitude (m) }\end{array}$ & $\begin{array}{c}\text { MDS photo } \\
\text { altitude (m) }\end{array}$ & $\begin{array}{c}\text { Errors (m) } \\
\text { Ortometric altitude } \\
\text { MDS altitude }\end{array}$ \\
\hline $\mathbf{1}$ & 101.678 & 12.92 & 88.758 & 88.928 & -0.171 \\
\hline $\mathbf{2}$ & 100.818 & 12.92 & 87.898 & 87.794 & 0.104 \\
\hline $\mathbf{3}$ & 101.121 & 12.92 & 88.201 & 87.993 & 0.208 \\
\hline $\mathbf{4}$ & 100.959 & 12.92 & 88.039 & 88.418 & -0.379 \\
\hline $\mathbf{5}$ & 102.62 & 12.92 & 89.700 & 89.737 & -0.037 \\
\hline
\end{tabular}

\section{CONCLUSIONS}

The aerophotogrammetric survey generates products with high spatial resolution. This work shows that there is always a horizontal positional displacement model in the same direction, e.g., the error is systematic and the vertical displacement error is centimetric.

The generated model without geometric correction can be used for analysis that do not require accuracy, however the generated jobs with control points increases the possibility of use, as is the case of environmental skilled services, mainly in small areas, due to the high spatial resolution of products submitted to support the registration of rural properties, especially for natural boundaries and areas of tough access for being orthorectified would contribute to the accuracy of the gathered information.

They also have potential for use in crops analysis and quantification of fauna and flora and the possibility of adjusting mainly the temporal and spatial resolutions and the low cost compared to manned aircraft.

Another factor that is worth mentioning is that aerial photographs are documents and will be part of the historical collection of the imaged area in the case of UFMS Research Base in Pantanal, which are available to the institution.

\section{ACKNOWLEDGEMENTS}

Special thanks to CAPES for granting doctoral level scholarship the first author. CNPq for financial support under the research projects (Process: 561923 / 2010-8; 310724 / 2011-2 and 305300 / 2012-1). The authors also thank the Foundation for Support to the Development of Education, Science and Technology of the State of Mato Grosso do Sul - FUNDECT, by the Regional Scientific Development scholarship, awarded to Gustavo Marques Amorim, who translated this material.

\section{REFERENCES}

ADÁMOLI, J. Vegetação e Flora. In: SIMPÓSIO SOBRE RECURSOS NATURAIS E SÓCIO-ECONÔMICOS DO PANTANAL, 1986, Corumbá. Anais...Corumbá, v. 1, p. 105106.

AGISOFT. Software Agisoft PhotoScan Professional Edition, Educational License, 2014.

ALVES JÚNIOR, L.R.; CÔRTES, J.B.R.; FERREIRA, M.E.; SILVA, J.R. Validação de ortomosaicos e Modelos Digitais de Superfície utilizando fotografias obtidas com câmera digital não métrica acoplada a um VANT. In: Simpósio Brasileiro de Sensoriamento Remoto, XVII, 2015, João Pessoa. Anais... João Pessoa: INPE, p. 2157 - 2164.

ALVES JÚNIOR, L.R.; CÔRTES, J.B.R.; FERREIRA, M.E. Validação de mosaicos aerofotogramétricos utilizando fotografias obtidas com câmara digital não métrica acoplada a um VANT. In: CONGRESSO BRASILEIRO DE CARTOGRAFIA, XXVI, 2014, Gramado. Anais... Gramado, p. 1-15.

AZMI, S.M.; BAHARIN, A.; ANUAR, A. Accuracy assessment of topographic mapping using UAV image integrated with satellite images. In: INTERNATIONAL SYMPOSIUM OF THE DIGITAL EARTH, 8, 2014, Malasia. Anais....Malasia: Earth and Environmental Science, p. 1-6.

BLUE MARBLE GEOGRAPHICS. Global Mapper, Version 13.2, Global Mapper Software, Hallowell, U. S. A., 2012.

BRASIL - Ministério do Desenvolvimento Agrário. Norma Técnica para Georreferenciamento de Imóveis Rurais. $3^{\mathrm{a}}$ ed. Instituto Nacional de Colonização e Reforma Agrária (INCRA). Brasília, 2013a.

BRASIL - Ministério do Desenvolvimento Agrário. Manual Técnico de Posicionamento: Georreferenciamento de Imóveis Rurais. $1^{\mathrm{a}}$ edição. Instituto Nacional de Colonização e Reforma Agrária (INCRA). Brasília. 2013b.

BRASIL. Lei n. 10.267, de 28 de agosto de 2001. Altera dispositivos das Leis n. 4.947, de 6 de abril de 1966, 5.868, de 12 de dezembro de 1972, 6.015, de 31 de dezembro de 1973, 6.739, de 5 de dezembro de 1979, 9.393, de 19 de dezembro de 1996, e dá outras providências. Diário Oficial da República 
Federativa do Brasil, n. 166, Seção 1, 29 ago. 2001. Available in:<http://www.planalto.gov.br/ccivil_03/leis

/LEIS_2001/L10267. htm>. Acesso em 11 de fevereiro de 2016.

CÂNDIDO, A.K.A.A.; SILVA, N.M.; BARBOSA, D.S. Dinâmica espacial e temporal do uso do solo e Índice de Vegetação por Diferença Normalizada (NDVI) em setor de cabeceira do Rio São Lourenço, Campo Verde, MT. Revista Ra'e Ga o espaço geográfico em análise, v. 33, p. 94-119, 2015a.

CÂNDIDO, A.K.A.A.; SILVA, N.M.; PARANHOS FILHO, A.C. Imagens de Alta Resolução Espacial de Veículos Aéreos Não Tripulados (VANT) no Planejamento do Uso e Ocupação do Solo. Anuário do Instituto de Geociências - Igeo, v. 38, n. 1, p. 147-156, 2015b.

ELTOHAMY, F. \& HAMZA, E.H. Effect of ground control points location and distribution on geometric correction accuracy of remote sensing satellite images. In: INTERNATIONAL CONFERENCE ON AEROSPACE SCIENCES \& AVIATION TECHNOLOGY, 13, 2009, Cairo. Anais... Cairo.

EVERAERTS, J. The use of unmanned aerial vehicles (UAVs) for remote sensing and mapping. The International Archives of the Photogrammetry. Remote Sensing and Spatial Information Sciences, v. 37, p. 1187-1192, 2008.

JENSEN, J.R. Sensoriamento Remoto do Ambiente: Uma perspectiva em recursos terrestres. São José dos Campos: Parêntese, 672p., 2011.

LIEW, L.H.; WANG, Y.C.; CHEAH, W.S. Evaluation of control points' distribution on distortions and geometric transformations for aerial images rectification. Procedia Engineering, v. 41, p. 1002-1008, 2012.

MARCATO JUNIOR, J. \& TOMMASELLI, A.M.G. Exterior orientation of CBERS-2B imagery using multi-feature control and orbital data. ISPRS Journal of Photogrammetry and Remote Sensing, v. 79, p. 219-225, 2013.

MIOTO, C.L.; PARANHOS FILHO, A.C.; ALBREZ, E.A Contribuição à Caracterização das Sub-Regiões do Pantanal. Entre-Lugar, Dourados, v.3, n. 6, p. 165-180, 2012.

OBORNE, M. Mission Planner, versão 2.35. Software livre. APM multiplataform autopilot, 2014. Disponível em: http://planner.ardupilot.com/. Acesso em 05 de Jun. 2014.

POTT, A.; OLIVEIRA, A.K.M.; DAMASCENO-JUNIOR, G.A.; SILVA, J.S.V. Plant diversity of the Pantanal wetland. Brazilian Journal of Biology, v. 71, n. 1, p. 265-273, 2011.

PROPP - Pró-Reitora de pesquisa e Pós-Graduação. Coordenadoria de Estudos do Pantanal. Universidade Federal de Mato Grosso do Sul - UFMS, 2014. Available in: $<$ http://www.propp.ufms.br/index.php?section=estudos_panta nal\&itemId=3>. Access on november december 10, 2015.

ZIEGLER, S. Plugin CadTools, versão 0.6.2. QGis 2.0. Plugin utilizado para obtenção do Azimute, 2014

Submetido em 14 de abril de 2016 Aceito em 16 de maio de 2017 